\title{
Az oktatás földrajzai: ideológiák, intézmények és területi tervezés
}

\section{Geographies of schooling: Ideologies, institutions and spatial planning - 14th Interdisciplinary Symposium on Knowledge and Space}

\author{
MIKLE GYÖRGY
}

\begin{abstract}
MIKLE György: PhD-hallgató, Eötvös Loránd Tudományegyetem, Társadalom- és Gazdaságföldrajzi Tanszék; 1117 Budapest, Pázmány P. sétány 1/c.; miklegyo@gmail.com

György MIKLE: PhD student, Department for Social and Economic Geography, Eötvös Loránd University; Pázmány P. sétány 1/c., H-1117 Budapest, Hungary; miklegyo@gmail.com
\end{abstract}

A Heidelbergi Egyetem Földrajzi Intézete tíz éve indította el tudományos rendezvénysorozatát, amelynek célja a tudás és a tér kapcsolatának elemzése, az ehhez kötődő kutatói párbeszéd ösztönzése. ${ }^{1}$ A 2016. szeptember 14. és 17. között tizennegyedik alkalommal megrendezett szimpóziumon az oktatás földrajzi aspektusairól esett szó. A Klaus Tschira Alapítvány által finanszírozott rendezvényen 20 előadó vett részt, akik 10 különböző országból érkeztek és 4 tudományterületet képviseltek. A 45 perces előadásokat 15 perces nyílt beszélgetés, vita követte; a program minden nap mühelybeszélgetéssel zárult. A rendezvény így lehetőséget biztosított a kutatók közötti intenzív párbeszédre, amelybe az előadók és a hallgatóság egyaránt bekapcsolódhatott. ${ }^{2}$

A szimpózium nyitóelőadását és köszöntőjét Peter Meusburger, a Heidelbergi Egyetem Földrajzi Intézetének szeniorprofesszora tartotta, aki áttekintette az oktatás földrajzi jellemzőit vizsgáló tudományos tevékenység fejlődését. Elöadásában rámutatott arra, hogy a kutatások fókuszának változásán túl azok szemlélete is folyamatosan alakult.

A szekciók öt fő kérdéskör mentén szerveződtek. Az első és a második szekció az oktatás igazgatásának területi szintjeivel, az ezekben bekövetkezett változásokkal és a változások hatásaival foglalkozott. A témakörben Holger Jahnke (Flensburgi Egyetem), David Giband (Perpignani Egyetem), Herbert Altrichter (Johannes Kepler Egyetem, Linz), valamint Thomas Coelen (Siegeni Egyetem) előadására került sor. Holger Jahnke Schleswig-Holstein példáján keresztül mutatta be az oktatásszervezési feladatok tartományi szintről lokális

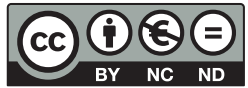


szintre való áthelyezésének hatásait. A helyi viszonyok különbözőségének, valamint az intézmények egyéni stratégiáinak következtében az intézményellátottságban és az oktatás színvonalában is a korábbinál jelentősebb területi különbségek alakultak ki a vidékies jellegü, csökkenő népességű tartományban. David Giband a franciaországi oktatási rendszer decentralizációjának hatásait vizsgálta, amelynek következtében megnőtt a helyi és az intézményi szint önállósága. Az előadó elsősorban arra fókuszált, hogy az önállósító törekvések dacára az intézmények miként kényszerülnek mégis a magasabb (nemzeti, illetve globális) területi szinteken zajló folyamatokhoz való alkalmazkodásra. Herbert Altrichter előadásában bemutatta, hogy az osztrák iskolák autonómiájának növekedése olyan versengő jellegű alapfokú oktatást hoz létre, amely az intézmények között informális alá-fölérendeltségi viszonyok kialakulását, valamint a tanulók szelekcióját indítja be. Az előadás - bár hasonló folyamatokat mutatott be - szemléletében némileg különbözött az előző kettőtől, ugyanis nagyobb hangsúlyt fektetett a diákokat ért hatásokra. Thomas Coelen az oktatás szervezésének és a városfejlesztés szempontjainak kölcsönhatásait részletezte németországi példákon keresztül. Amint bemutatta, a tudatos oktatásszervezés és a várostervezés egymást jól kiegészítik, a megfelelően átgondolt fejlesztések egyszerre képesek pozitív hatást gyakorolni mindkét szférára.

A második témakör a tanulói létszám alapján elkülöníthető oktatásszervezési modellek összehasonlítását foglalta magában, vagyis mérlegre kerültek a nagyobb és a kisebb iskolák mellett és ellen szóló érvek. Rune Kvalsund (Voldai Főiskola) a kisméretű vidéki iskolák hatékonysága mellett érvelt a nagyobb méretü városiakkal szemben, valamint a Norvégiában tapasztalható iskolabezárások ellenében foglalt állást. Ennek során olyan szempontokat emelt ki, mint a helyi társadalmi, illetve természeti viszonyokhoz való alkalmazkodóképesség, az irányukban megnyilvánuló nyitottság vagy az iskolákban zajló oktatás rugalmassága. Sam Hillyard és Carl Bagley (Durhami Egyetem) etnográfiai szemléletű kutatásában két angol vidéki iskola vizsgálatán keresztül mutatott rá arra, hogy a helyi társadalmi kontextus jelentősen befolyásolja a falusi iskolák életét. A köztudatban élő kép szerint a vidéki iskolák és a helyi közösség kapcsolata nagyon szoros, az iskolaigazgatók pedig fontos szerepet játszanak az iskolák életében, így a települési folyamatokban. Az előadók szerint a kérdés valójában ennél árnyaltabb, és elsősorban az adott kulturális-történeti közegtől függ, hogy milyen ezeknek a szereplőknek az egymáshoz való viszonya. A szekció záróelőadásában Caroline Kramer (Karlsruhei Technológiai Intézet) az oktatási rendszerben végbemenő átalakulásoknak a kisméretű iskolákra gyakorolt hatását mutatta be. Vizsgálatát Baden-Württemberg és Vorarlberg vidéki térségeiben végezte, amelyeket 25 évvel korábbi kutatásában is elemzett. Az előadás fö mondandója az volt, hogy a döntéshozatal különböző területi szintjei kölcsönösen képesek befolyásolni egymást, a kisméretủ iskolákkal kapcsolatos döntéshozói hozzáállást maguk az intézmények is aktívan formálják. 
A harmadik témakör az iskolák és a társadalom viszonyát dolgozta fel. Andrea Raggl (Vorarlbergi Tanárképző Főiskola) két nyugat-ausztriai falusi iskola példáját mutatta be, amelyek az úgynevezett Montessori-modellt vették át. A korábban a bezárás szélén álló iskolák a profilváltás következtében egyre népszerübbé váltak, elsősorban a közeli városban élő családok körében. Ez az új helyzet sajátos konfliktust hoz létre a helyi közösség és az iskolákban egyre nagyobb számban megjelenő városi diákok között, akiknek családja általában a helyieknél magasabb társadalmi státusszal bír. Christian Reutlinger (St. Galleni Főiskola) társadalmi problémákkal küzdő városrészekben vizsgálta az iskolában dolgozó pedagógusoknak a helyi közeghez füződő viszonyát. Kutatásának módszertani szempontból lényeges eleme volt, hogy a gyerekek nézőpontjából mutatta be a társadalmi problémáknak az iskolákban való lecsapódását. A szekció utolsó előadását Peter Kraftl (Birminghami Egyetem) tartotta, távolléte miatt Skype-kapcsolat segítségével. A prezentáció az Egyesült Királyságban egyre elterjedtebb nyitott és önkéntes alapon müködő farmok (care farms) szerepét részletezte az alternatív oktatási módok között, kitért továbbá a farmok és a környezetükben található vidéki közösségek kapcsolatára, kölcsönhatására is.

A szimpózium harmadik napjának két szekciójában az oktatási rendszerek változásait térbeli-történeti perspektívából vizsgáló előadások kerültek sorra. Gyuris Ferenc (Eötvös Loránd Tudományegyetem) a magyar vidéki iskolahálózat átalakulását mutatta be a két világháború közötti állapotoktól a Kádár-korszakig. Az elsősorban az Alföldre, így javarészt a tanyasi iskolák sorsára fókuszáló előadásban rámutatott arra, hogy az alapfokú oktatás mindenkori helyzete az éppen aktuális politikai célok mentén alakult. Így a kultúrfölény ideológiáját magáévá tévő oktatáspolitika iskolaépítő tevékenysége, majd a tanyasi iskolákkal való politikai-ideológiai szembehelyezkedés, később pedig a racionalizáció jelszava mentén véghezvitt iskolabezárások végső soron mindig az adott rendszer politikai céljaihoz igazodtak. Artur Bajerski (Adam Mickiewicz Egyetem, Poznań) a lengyel iskolahálózat napjainkban megfigyelhető területi különbségeinek történeti hátterére mutatott rá. Mivel a mai Lengyelország területe az iskolahálózat kiépülésének időszakában több nagyhatalom (Poroszország, Orosz Birodalom, Habsburg Birodalom) fennhatósága alá tartozott, az intézményhálózat jellemzőiben (az intézmények jellege, intézményekkel való ellátottság) is jól megfigyelhető és ma is jelenlévő területi különbségek alakultak ki. Anne Sliwka (Heidelbergi Egyetem) a kamaszkorúak oktatásának újfajta modelljeit részletezte, amelyek elsősorban az angolszász országokban népszerüek, alapfilozófiájuk pedig a diákok bevonása, kibontakoztatása. Silvie Rita Kučerová (Jan Evangelista Purkyně Egyetem, Ústí nad Labem) Csehország példáján keresztül mutatta be a szocialista rendszer és a rendszerváltás utáni iskolamodellek közötti különbségeket. Az iskolák fenntartása az államtól az önkormányzatok kezébe került, így amíg korábban az esélyegyenlőség nevében tartották fenn az intézményeket, újabban az iskolák a helyi közösségek fenntartásának kulcsszereplőivé váltak. Fabian Kessl (Duisburg-Esseni Egyetem) két 
oktatásfilozófiai modell összehasonlítását végezte el. Az egyik gondolat Ivan Illich osztrák filozófustól származik, aki az 1970-es években az oktatás liberalizálása mellett érvelt, amelynek eredményeként az oktatás informális formában zajlana és elsősorban lehetőségként merülne fel. A másik, ezzel ütköző modell David Hartley-hoz kötődik, aki az 1990-es években a neoliberális gazdasági rendszer térnyerése és így az oktatás liberalizációja mögött annak piacosodását, az oktatásban részvevőknek pedig ilyen módon fogyasztókká alakulását vélte felfedezni, amellyel szemben állást is foglalt.

Az utolsó szekció három előadása bemutatta, hogy az oktatás miképpen válik napjainkban is politikai, illetve geopolitikai célok kiszolgálójává. Laura Schaefli (Queen's Egyetem, Kingston) a kanadai közoktatás egy kevésbé ismert oldalára világított rá, jelesül hogy miként válik az oktatás az őslakos népesség diszkriminációjának és ellehetetlenítésének eszközévé. Sarah Holloway (Loughborough-i Egyetem) a - közoktatásban egyre elterjedtebb - tanórákon kívüli foglalkozások szerepét emelte ki a társadalmi különbségek újratermelésében, ezen belül is elsősorban a társadalmi osztálykülönbségek, valamint a társadalmi nem (gender) dimenzióját hangsúlyozta. Ranu Basu (York Egyetem, Toronto) Kanadába érkezett menekültek és bevándorlók példáján keresztül mutatott rá a közoktatásban megfigyelhető negatív megkülönböztetésre.

A szimpózium a résztvevők viszonylag kis létszáma, valamint a párbeszédre lehetőséget adó programtervezet következtében (az előadásokat követő vitákon, illetve műhelybeszélgetéseken túl fontos kiemelni az ebéd- és kávészüneteket, amelyek kötetlenebb, spontán beszélgetésekre adtak lehetőséget) megfelelő fóruma volt a különböző országokból és különböző tudományterületekről érkező kutatók eszmecseréjének. A különböző nemzeti, illetve diszciplináris háttér miatt néhány esetben felmerültek definíciós, fogalomhasználati különbségek, amelyeket a viták során igyekeztek tisztázni a részvevők. Az előadások általános tanulságokkal is szolgáltak. Több előadás alapján is kirajzolódott az oktatás neoliberális átalakulásának tendenciája. Ennek egyik fontos jellemzője az állami szerepvállalás csökkenése az iskolák fenntartásában, valamint a különböző alternatív oktatási formák térnyerése, végső soron pedig az oktatás piacosodása, fogyasztási cikké válása. A történeti szemléletű előadások elsősorban arra mutattak rá, hogy a politikai célok elérését, bizonyos társadalmi csoportok ellenőrzését, befolyásolását, illetve általában a társadalmi folyamatok alakítását többféle földrajzi-történeti kontextusban az oktatáson keresztül is végezték a döntéshozók. Az oktatáspolitikának ez az aspektusa továbbra is aktuális, így napjainkban is fontos hatalmi tényezőnek számít.

\section{Jegyzetek}

$1 \quad$ A rendezvénysorozat koncepciójáról lásd Czirfusz (2012); korábbi szimpóziumokról Czirfusz (2009) és Gyuris (2010) számoltak be. 
2 A szimpózium részletes programja megtalálható a http://www.knowledgeandspace.unihd.de/honlapon, valamint a rendezvényen készült fényképek és videók is itt elérhetőek. Az előadások írott változata tanulmánykötetben fog megjelenni a Springer Kiadó gondozásában.

\section{Irodalom}

Czirfusz M. (2009): Knowledge and Power - 7th Interdisciplinary Symposium on Knowledge and Space. Heidelberg, Németország, 2009. június 17-20. Tér és Társadalom, 3., 199-203.

Czirfusz M. (2012): A tudás regionális különbségeiről, tudományos miliőről, hálózatokról és kapcsolatokról: Interjú Peter Meusburgerrel. Tér és Társadalom, 1., 158-168.

Gyuris F. (2010): Knowledge and Action - 9th Interdisciplinary Symposium on Knowledge and Space. Tér és Társadalom, 2., 153-159. 